\title{
TINDAK PIDANA PEMILU LEGISLATIF DI KABUPATEN BANYUMAS DAN PURBALINGGA

\author{
(Studi tentang Kebijakan Formulasi dan Penerapan \\ Undang-Undang No. 10 Tahun 2008 Tentang Pemilihan Umum)
}

\author{
Suharso Agung Basuki \\ Keuskupan Purwokerto
}

\begin{abstract}
Legislative General Election 2009 has opening the opportunity to return sovereignty to people. Therefore, in article entitling, Writer interest to study The Crime of legislative general election which formulated in Code Number 10 Year 2008 concerning General Election Of Member of DPR, DPRD, and DPD, and applying of The Crime of General Election in Sub-Province of Banyumas and Purbalingga at GENERAL ELECTION 2009, which conducted by using yuridis normative approach. Pursuant to research, the crime sanction system in general election have the character of cumulative which it is merger of prison sanction and penalty at the same time that imposed to perpetrator. This matter digresses from crime system in KUHP Section 10. 94 of general election crime in Sub-Province of Banyumas and Sub-Province of Purbalingga only 3 processed. Two judge decisions have execution power, whereas the other decision have discharge defendant from all prosecution or ontslag van of ale rechtvervolging (in Sub-Province of Banyumas). Therefore, writer raise recommendation : cause of the number of Parties participant in general election which many collisions in General, so that this code have to reform again, at specially in the case of penalty and prison sanction, and The Stopping of investigation in police level and public attorney don't be easy to conducted.
\end{abstract}

Keyword: general election, crime, sanction, applying of law.

\begin{abstract}
Abstrak
Pemilu Legislatif 2009 membuka peluang untuk mulai mengembalikan kedaulatan kepada rakyat. Tulisan ini membahas formulasi tindak pidana pemilu legislatif yang dirumuskan dalam UndangUndang Nomor 10 Tahun 2008 Tentang Pemilihan Umum Anggota DPR, DPRD, dan DPD, serta penerapan Tindak Pidana PEMILU di Kabupaten Banyumas dan Purbalingga pada PEMILU 2009, yang dilakukan dengan menggunakan pendekatan yuridis normatif. Berdasarkan hasil penelitian, sistem sanksi pidana dalam tindak pidana pemilu bersifat komulatif yaitu penggabungan sanksi pidana penjara dan denda sekaligus dikenakan kepada pelaku. Hal ini menyimpang dari sistem pemidanaan dalam KUHP Pasal 10 dan dari Dari 94 tindak pidana pemilu yang ada di Kabupaten Banyumas dan Kabupaten Purbalingga hanya 3 tindak pidana pemilu yang diproses hukum. Dua putusan hakim telah berkekuatan hukum tetap, sementara putusan yang satunya melepaskan terdakwa dari segala tuntutan hukum atau ontslag van ale rechtvervolging (di Kabupaten Banyumas). Oleh karena itu, penulis mengajukan saran : Banyaknya Partai peserta pemilu yang banyak melakukan pelanggaran Pemilu dalam undang-undang ini, sehingga undang-undang ini perlu direvisi, dalam hal sanksi dan denda, minimal dan maksimumnya dan Penghentian penyidikan di tingkat kepolisian dan kejaksaan jangan mudah dilakukan, harus diselesaikan dengan sungguh-sungguh.
\end{abstract}

Kata kunci : pemilihan umum, tindak pidana, sanksi, penerapan hukum 


\section{Pendahuluan}

Berdasarkan Pasal 1 angka (1) Undangundang Nomor 10 Tahun 2008 tentang Pemilihan Umum, pemilihan umum adalah sarana pelaksanaan kedaulatan rakyat yang dilaksanakan secara langsung, umum, bebas, rahasia, jujur, dan adil dalam Negara Kesatuan Republik Indonesia berdasarkan Pancasila dan UUD 1945, sedangkan menurut Pasal 6 angka (1) Pemilihan Umum untuk memilih annggota DPR, DPD, DPRD provinsi dan DPRD Kabupaten/kota diselenggarakan oleh Komisi Pemilihan Umum (KPU) dan angka (2) Pengawasan penyelenggaraan Pemilu dilaksanakan oleh Bawaslu.

Raymond Toruan dalam sebuah tulisannya mengemukakan, “... pemilihan umum yang diselenggarakan pada tahun 2009 adalah pemilihan umum yang ketiga semenjak reformasi tampil di atas panggung politik nasional". Hal itu berarti bahwa enam kali pemilihan umum telah dilewatkan sepanjang sejarah Orde Baru. Dalam kurun waktu tiga puluh tahun terdapat beberapa prinsip yang dipertahankan sebagai asas pemilihan umum, yaitu langsung-umum, bebas dan rahasia (Luber). Dalam ketiga asas tersebut secara implisit mengandung nilai, bahwa pemilihan umum dilaksanakan pula secara jujur dan adil (Jurdil). Namun pengalaman selama ini memberikan kesan yang cukup kuat bahwa implementasi prinsip-prinsip tersebut dalam penyelenggaraan pemilihan umum masih banyak menimbulkan kontroversi dan permasalahan.

Tahun 2009 merupakan tahun pemilu ketiga sejak mulainya era Reformasi dan belum mencerminkan perwujudan kedaulatan rakyat. Anggota DPR maupun DPRD bukan pilihan rakyat, melainkan pilihan partai politik. Presiden dan wakil presiden bukan merupakan pilihan rakyat, melainkan pilihan DPR. Pemegang kedaulatan adalah partai politik yang menguasai kursi di DPR dan DPRD. Lembaga legislatif maupun eksekutif belum perlu bertanggungjawab (akuntabel) kepada rakyat, melainkan kepada parpol penghuni DPR dan DPRD. Pemilu Legislatif yang diselenggarakan pada April 2009 membuka peluang untuk mulai mengembalikan kedaulatan kepada rakyat. Apabila sebagian (besar) anggota DPR dan DPRD nanti benar-benar adalah hasil pilihan rakyat, Indonesia akan memiliki legislatif yang lebih independen dari parpol dan lebih akuntabel terhadap rakyat yang memilihnya. ${ }^{1}$

Tindak Pidana Pemilu menurut UndangUndang Nomor 10 Tahun 2008, diatur dalam ketentuan Pasal 252 yang menentukan bahwa planggaran pidana Pemilu adalah pelanggaran terhadap ketentuan pidana Pemilu yang diatur dalam Undang-Undang ini yang penyelesaiannya dilaksanakan melalui pengadilan dalam lingkungan peradilan umum. Tindak pidana pemilu yang terjadi di wilayah Kabupaten Banyumas dan Kabupaten Purbalingga keduanya telah melakukan upaya hukum sampai dengan ke tingkat banding sesuai dengan Pasal 255 ayat (5) Undang-undang Nomor 10 Tahun 2008.

\section{Permasalahan}

Berdasarkan latar belakang tersebut, penulis tertarik untuk membahas mengenai formulasi tindak pidana pemilu legislatif yang dirumuskan dalam Undang-Undang Nomor 10 Tahun 2008 Tentang Pemilihan Umum Anggota DPR, DPRD, dan DPD dan penerapan aturan tindak pidana PEMILU di Kabupaten Banyumas dan Purbalingga pada PEMILU 2009.

\section{Metode Penelitian}

Tipe penelitian yang digunakan adalah yuridis normatif. Spesifikasi Penelitian yang digunakan adalah deskriptif analistas. Dalam penelitian ini penulis mengambil contoh kasus tindak pidana pemilu yang terjadi di dua wilayah Kabupaten Banyumas dan Purbalingga dan sebagai sumber data sekunder diperoleh dari POLRES Banyumas dan POLRES Purbalingga, Pengadilan Negeri Purwokerto dan Pengadilan Negeri Purbalingga, PANWASLU/ KPU Kabupaten Banyumas dan PANWASLU/ KPU Kabupaten Purbalingga, khususnya dalam bentuk dokumendokumen hukum pelanggaran tindak pidana pemilu. Data sekunder lain diperoleh dari peraturan perundang-undangan, referensi-referensi, putusan-putusan dan dokumen-dokumen yang

\footnotetext{
1 Raymond Toruan, 2009, Saatnya Bertanggungjawab. Majalah Hidup, Edisi 15 Meret 2009, Jakarta, hlm. 4.
} 
berhubungan dengan permasalahan penelitian. Dalam penelitian ini, data sekunder yang di peroleh diinventarisasi yang kemudian dicatat berdasarkan relevansinya dengan permasalahan yang akan diteliti kemudian disestematisasikan menjadi satu kesatuan, kemudian data disajikan dalam bentuk uraian-uraian yang disusun secara sistematis.

\section{Pembahasan}

Formulasi Tindak Pidana Pemilu Legislatif dalam Undang-Undang Nomor 10 Tahun 2008 Tentang Pemilihan Umum Anggota DPR, DPRD, dan DPD

Kebijakan hukum pidana pada hakikatnya mengandung kebijakan mengatur/mengalokasi dan membatasi kekuasaan, baik kekuasaan/ kewenangan warga masyarakat pada umumnya, untuk bertindak/bertingkah laku dalam pergaulan masyarakat) maupun kekuasaan atau kewenangan penguasa/penegak hukum. Dilihat dari aspek hukum pidana yang demikian, maka dapat dikatakan bahwa masalah dasar hukum pidana terletak di luar bidang hukum pidana itu sendiri, yaitu di bidang hukum tata negara. ${ }^{2}$

Formulasi tindak pidana pemilu legislatif dalam Undang-Undang No. 10 Tahun 2008 tentang Pemilihan Umum Anggota DPR, DPRD, dan DPD maka kebijakan hukum pidana yang telah ditentukan dalam Undang-undang tersebut, berdasarkan hasil penelitian, pasal-pasal yang dianalisis dirumuskan memenuhi unsur-unsur pidana dalam hal ini yaitu unsur tindak pidana Pemilu, adapun pasal yang memenuhi unsurunsur tindak pidana pemilu dimaksud adalah Pasal 260 sampai dengan Pasal 311. Berdasarkan identifikasi terhadap perumusan tindak pidana Pemilu dalam UU No. 10 Tahun 2008, dapat dikemukakan bahwa dari aspek perbuatan, pelaku dan sanksi pidana terdapat kekhususan.

Kekhusuan yang ada pada aspek perbuatan antara lain menyebabkan orang lain kehilangan hak pilihnya; memberikan keterangan yang tidak benar mengenai diri sendiri atau diri orang lain tentang sesuatu hal yang diperlukan untuk pengisian daftar pemilih; dengan keke-

\footnotetext{
2 Barda Nawawi Arief, 1998. op.cit, hlm. 30.
}

rasan atau ancaman kekerasan atau dengan menggunakan kekuasaan yang ada padanya saat pendaftaran pemilih; menghalang-halangi seseorang untuk terdaftar sebagai pemilih dalam Pemilu menurut undang-undang ini; tidak memperbaiki daftar pemilih sementara setelah mendapat masukan dari masyarakat; tidak menindaklajunti temuan Bawaslu, Panwaslu Propinsi/ Kota; melalukan perbuatan curang untuk menyesatkan seseorang atau dengan memaksa atau menjajika, atau memberikan uang atau materi lainnya; pembuat surat atau dokumen dengan maksud memaksa untuk memakai atau menyuruh orang memakai, atau menggunakan surat atau dokumen yang dipalsukan untuk bakal calon DPR, DPD dan DPRD; tidak menindaklanjuti temuan Bawaslu/Panwaslu untuk verifikasi partai politik calon peserta pemilu; melakukan kampanye diluar jadwal yang telah di tentukan oleh KPU; melanggar larangan pelaksanaan kampanye; menjajikan atau memberikan uang untuk tidak memilih peserta pemilu tertentu; memberi atau menerima dana kampanye yang melebihi ketentuan.

Aspek selanjutnya dari perbuatan yang termasuk pada kategori kekhususan undangundang Pemilu adalah mengacaukan, menghalangi, atau mengganggu jalannya kampanye Pemilu; karena kelalaiannya mengakibatkan terganggunya tahapan penyelanggaraan Pemilu di tingkat desa/kelurahan; memberikan keterangan tidak benar dalam laporan dana kampanye; mengumumkan hasil survei atau hasil jajak pendapat dalam masa tenang; menetapkan jumlah surat suara yang dicetak melebihi jumlah yang ditentukan; tidak menjaga kerahasiaan, keamanan, dan keutuhan surat suara; supaya tidak menggunakan hak pilinnya atau memilih peserta pemilu tertentu atau menggunakan hak pilihnya dengan cara tertentu sehingga suaranya tidak sah; menggunakan kekerasan atau ancaman kekerasan dan/atau menghalangi seseorang yang akan melakukan haknya untuk memilih atau melakukan kegiatan yang menimbulkan gangguan ketertiban atau ketentraman pelaksanaan pemungutan.

Perbuatan-perbuatan di bawah ini juga termasuk kategori perbuatan yang dilarang da- 
lam undang-undang Pemilu, yaitu melakukan perbuatan yang menyebabkan suara seorang pemilih menjadi tidak bernilai atau menyebabkan peserta pemilu tertentu mendapat tambahan suara atau perolehan suara peserta pemilu menjadi berkurang; pada saat pemungutan suara mengaku dirinya sebagai orang lain; memberikan suara lebih dari satu kali di satu atau lebih TPS; menggagalkan pemungutan suara; tidak memberikan kesempatan kepada seorang pekerja untuk memberikan suaranya pada pemungutan suara, kecuali dengan alasan bahwa pekerjaan tersebut tidak bisa ditinggalkan; merusak atau menghilangkan hasil pemungutan suara; tidak memberikan surat suara pengganti hanya satu kali kepada pemilih yang menerima surat suara yang rusak; Memberikan pilihan kepada pemilih lain; Tidak menetapkan pemungutan suara ulang di TPS; menyebabkan rusak atau hilangnya berita acara pemungutan dan perhitungan suara dan sertifikat penghitungan suara yang sudah disegel; mengubah berita acara hasil penghitungan suara dan/atau sertifikat hasil penghitungan suara; mengakibatkan hilang atau berubahnya berita acara hasil rekapitulasi penghitungan perolehan suara dan/atau sertifikat penghitungan suara; merusak, menggangu, atau mendistorsi sistem informasi penghitungan suara hasil Pemilu.

Aspek lain dari perbuatan yang termasuk terlarang adalah tidak membuat dan menandatangi berita acara perolehan suara peserta pemilu dan calon anggota DPR, DPD dan DPRD; tidak memberikan salinan satu eksemplar berita acara pemungutan dan penghitungan suara kepada saksi peserta pemilu, Panwas Lapangan, PPS dan PPK melalui PPS; tidak menjaga, mengamankan keutuhan kotak suara, dan menyerahkan kotak suara tersegel yang berisi surat suara, berita acara pemungutan suara dan sertifikat hasil penghitungan suara kepada PPK melalui PPS atau kepada PPLN bagi KPPSLN pada hari yang sama; tidak mengawasi penyerahan kotak suara tersegel kepada PPK dan Panwaslu kecamatan yang tidak mengawasi kotak suara tersegel kepada Panwaslu Kabupaten/ kota; tidak mengumumkan hasil penghitungan suara dari seluruh TPS di wilayah kerjanya; me- lakukan penghitungan cepat dan mengumumkan hasil penghitungan cepat pada hari/tanggal pemungutan suara; tidak memberitahukan bahwa hasil penghitungan cepat bukan hasil resmi pemilu; tidak melaksanakan putusan pengadilan; tidak menindaklanjuti temuan dan/atau laporan pelanggaran pemilu.

Tergolong pada kategori pelaku pada tindak pidana pemilu, antara lain setiap orang/ lembaga; petugas PPS/PPLN; setiap anggota KPU, KPU Provinsi/Kabupaten; setiap Ketua/ Wakil Ketua/Ketua Muda/Hakim Agung/Hakim Konstitusi, hakim-hakim pada semua badan peradilan, Ketua dan wakil ketua BPK, Gubernur, Deputi Gubernur Senior dan Deputi Gubernur Bank Indonesia serta pejabat BUMN/BUMD; anggota KPU, KPU Propvinsi/Kabupaten/Kota, Sekjen KPU, Pegawai Sekretariat KPU/KPUP/ KPUD, Sekretaris KPU/KPUD dan pegawai sekretariat KPU/KPUD; setiap pelaksana, peserta, atau petugas kampanye; setiap perusahaan pencetak surat suara; seorang majikan/ atasan; ketua dan anggota KPPS/KPPSLN; setiap KPPS/ KPPSLN; setiap Pengawas Pemilu Lapangan; setiap PPK; ketua dan Anggota KPU, KPU Provinsi/Kabupaten/Kota; ketua dan Anggota Bawaslu, Panwaslu Provinsi/Kabupaten/Kota, Kecamatan dan/ atau PPL/ PPLLN.

Sanksi pidana pada tindak pidana pemilu dapat digolongkan menjadi dua, yaitu yang teringan dan terberat. Sanksi pidana yang terringan ada pada Pasal 261, yang menentukan bahwa pelaku tindak pidana pemilu dapat di pidana dengan pidana penjara paling singkat 3 (tiga) bulan dan paling lama 12 (dua belas) bulan dan denda paling sedikit Rp. 3.000.000,- (tiga juta rupiah) dan paling banyak Rp. 12.000. 000,- (dua belas juta rupiah). Sedangkan sanksi pidana terberat ada pada Pasal 284 Jo Pasal 146 ayat (1) yang menentukan bahwa pelaku tindak pidana dapat dipidana dengan pidana penjara paling singkat 24 (dua puluh empat) bulan dan paling lama 48 (empat puluh delapan) bulan dan denda paling sedikit Rp. 500 . 000.000,- (lima ratus juta rupiah) dan paling banyak Rp. 10.000.000.000,- (sepuluh miliar rupiah) 
Sistem sanksi pidana dalam tindak pidana pemilu bersifat komulatif yaitu penggabungan sanksi pidana penjara dan denda sekaligus dikenakan kepada pelaku. Hal ini menyimpang dari sistem pemidanaan dalam KUHP Pasal 10, karena dalam KUHP, pidana pokok hanya dapat dijatuhkan satu jenis pidana pokok saja, tidak boleh antara jenis-jenis pidana pokok dijatuhkan secara bersama-sama.

Penerapan Tinda Pidana PEMILU di Kabupaten Banyumas dan Purbalingga pada PEMILU 2009

Proses penanganan tindak pidana pemilu dapat digambarkan melalui bagan sebagai berikut:

\section{Bagan 1.}

Alur Proses Penanganan Tindak Pidana Pemilu

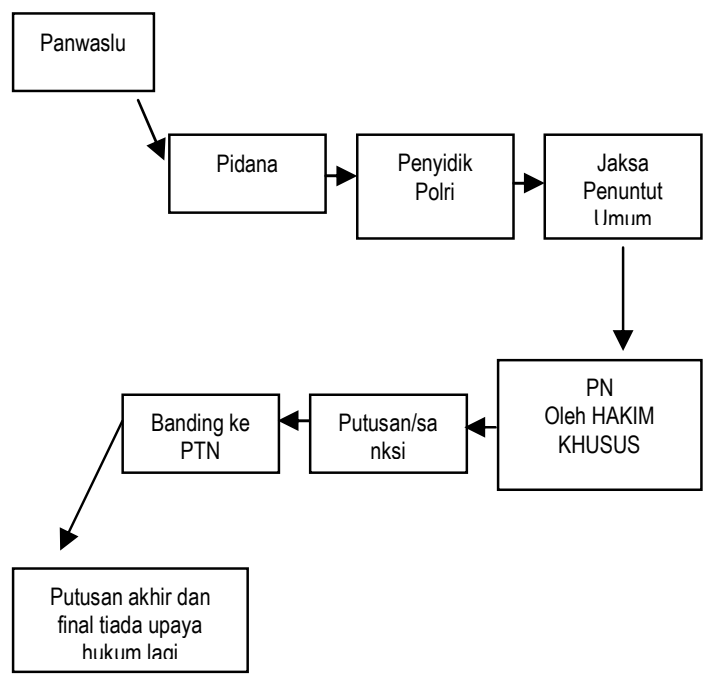

Pelanggaran pemilu adalah segala bentuk kegiatan yang di lakukan oleh peserta pemilu dari partai politik, peserta persorangan, pelaksana, peserta, petugas yang ditunjuk oleh peserta pemilu, orang perseorangan maupun penyelenggara pemilu dengan sengaja maupun tidak dan kegiatan tersebut melanggar perundang-undangan atau peraturan lainnya. Penyelesaian pelanggaran pemilu diatur dalam UU No. 10 Tahun 2008 secara umum diselesaikan melalui Bawaslu, Panwaslu sesuai tingkatannya sebagai lembaga yang memiliki kewenangan melakukan pengawasan terhadap setiap tahapan pelaksanaan pemilu. Dalam proses pengawasan tersebut, Bawaslu, dan/atau Panwaslu, sesuai tingkatannya, dapat melakukan temuan, menerima laporan, dan melakukan kajian atas laporan dan temuan adanya dugaan pelanggaran, dan meneruskan temuan dan laporan di maksud kepada instansi yang berwenang yaitu KPU terhadap pelanggaran administrasi, penyidik/polisi terhadap dugaan tindak pidana.

Pelanggaran pemilu yang bersifat administrasi menjadi kewenangan KPU, sesuai tingkatannya, untuk menyelesaikannya. Berdasarkan sifatnya, sanksi terhadap pelanggaran administrasi adalah sanksi administrasi. Khusus terkait dengan pelanggaran yang dilakukan oleh penyelenggara, maka KPU dapat menggunakan Peraturan KPU tentang Kode Etik KPU.

\section{Bagan 2.}

Alur penanganan pelanggaran pemilu 2009

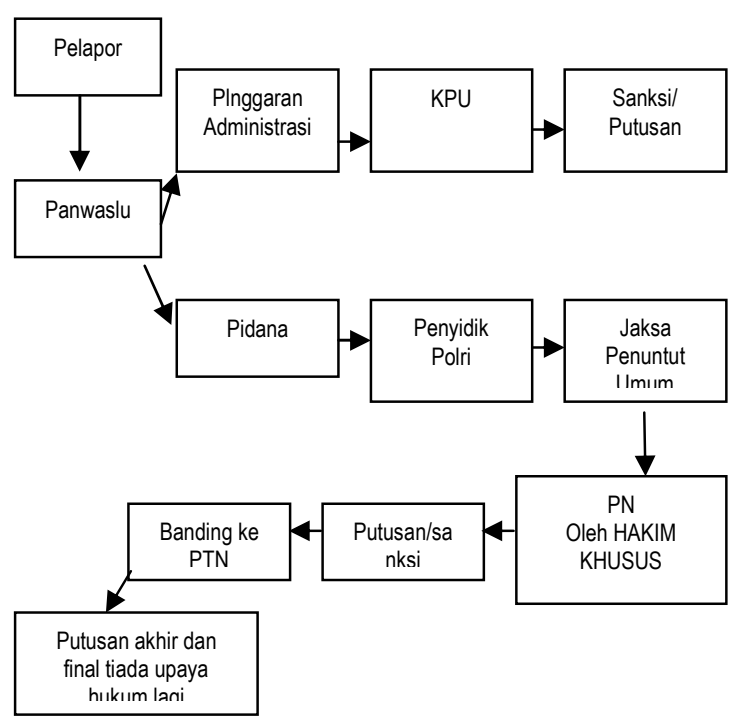

Pelanggaran Pidana Pemilu dan Penanganannya.

Berdasarkan temuan dan laporan pelanggaran Pemilu, baik yang dilaporkan langsung ke Panwaslu Kabupaten Banyumas maupun yang dilaporkan melalui Panwaslu Kecamatan, selama penyelenggaraan Pemilu DPR, DPD, DPRD Tahun 2009, terdapat 50 (lima puluh) kasus Pelanggaran Pidana Pemilu. Tindak lanjut berbagai pelanggaran pidana pemilu tidak semuanya ditangani langsung oleh Panwaslu di tingkat Kabupaten Banyumas, namun beberapa di antaranya yang ditangani oleh Panwaslu tingkat kecamatan, dengan berkoordinasi dengan PPK. Berikut disajikan data mengenai laporan Pelanggaran Pidana Pemilu dan penanganannya 
yang terjadi di masing-masing tahapan, yang terjadi wilayah kerja Panitia Pengawas Pemilu Kabupaten Banyumas.

Tabel 1.

Statistik Kriminal Pemilu 2009 Kabupaten Banyumas dan Purbalingga

\begin{tabular}{|c|c|c|c|c|c|c|c|c|}
\hline \multirow[t]{2}{*}{ No } & \multirow{2}{*}{$\begin{array}{c}\text { Dilapor } \\
\text { kan ke } \\
\text { Panwas } \\
\text { lu }\end{array}$} & \multirow[t]{2}{*}{ TP } & \multirow{2}{*}{$\begin{array}{c}\text { ke } \\
\text { Peny } \\
\text { idik }\end{array}$} & \multirow{2}{*}{$\begin{array}{c}\text { Ke } \\
\text { Kejak } \\
\text { saan }\end{array}$} & \multirow{2}{*}{$\begin{array}{l}\mathrm{Ke} \\
\mathrm{PN}\end{array}$} & \multicolumn{2}{|c|}{ Diputus } & \multirow[b]{2}{*}{$\begin{array}{l}\text { B } \\
\text { D } \\
\text { G }\end{array}$} \\
\hline & & & & & & \begin{tabular}{|c|} 
Di \\
pidana
\end{tabular} & $\begin{array}{c}\text { Tdk } \\
\text { di pi- } \\
\text { dana }\end{array}$ & \\
\hline 1. & Bms & 51 & 2 & 2 & 2 & 1 & 1 & 2 \\
\hline 2. & $\mathrm{Pbg}$ & 43 & 1 & 1 & 1 & 1 & - & 1 \\
\hline
\end{tabular}

Keterangan :

Bms : Banyumas

TP : Tindak Pidana

PN : Pengadilan Negeri

Sumber : dari Panwaslu Banyumas dan

Purbalingga

Bagan 3.

Penanganan laporan di bawaslu

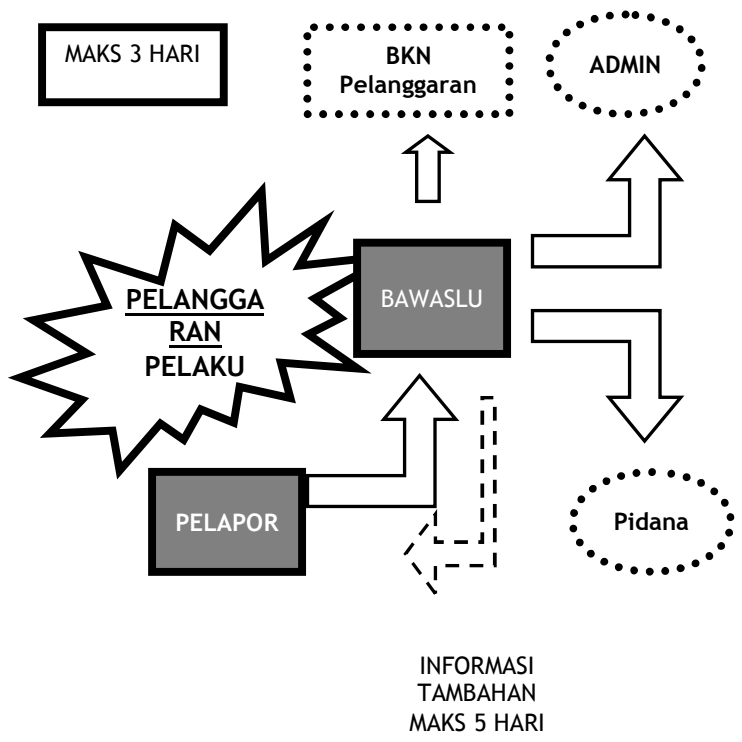

Pertama, pemutakhiran data pemilih dan penyusunan daftar pemilih, keterlambatan pembentukan panwaslu kabupaten/kota, telah mengakibatkan tidak terawasinya tahapan pemutakhiran dan penyusunan daftar pemilih. $\mathrm{Na}$ mun demikian, sejak dilantik pada tanggal 24 Oktober 2008, Panwaslu Kabupaten Banyumas tetap melakukan pengawasan DPT. Namun demikian, Panwaslu Kabupaten Banyumas tidak menemukan dan menerima laporan dugaan
Pelanggaran Pidana Pemilu yang berkaitan dengan pemutakhiran data dan penyusunan daftar pemilih.

Kedua, pendaftaran peserta pemilu, pada tahapan ini Panwaslu Kabupaten Banyumas belum terbentuk, sehingga Panwaslu Kabupaten Banyumas tidak dapat menjelaskan Pelanggaran Pidana Pemilu yang terjadi pada tahapan ini. Ketiga, penetapan peserta pemilu, seperti tahapan sebelumnya, pada tahapan ini Panwaslu Kabupaten Banyumas masih belum terbentuk, sehingga Panwaslu Kabupaten Banyumas tidak dapat menjelaskan pelanggaran Pemilu yang terjadi pada tahapan tersebut.

Keempat, penetapan jumlah kursi dan daerah pemilihan, bahwa pada tahapan penetapan jumlah kursi dan daerah pemilihan, Panwaslu Kabupaten Banyumas masih belum terbentuk, maka tidak dapat menjelaskan pelanggaran Pemilu yang terjadi pada tahapan ini.

Kelima, pencalonan anggota DPR, DPD dan DPRD, pelanggaran pidana pemilu pada tahapan pencalonan Angota DPR, DPD, DPRD, tahun 2009 berupa dugaan penggunaan dokumen palsu, telah dilaporkan oleh Joko Suratno (Ketua Panwaslu Kecamatan Cilongok). Pelapor melaporkan Muhyi Fadlil (Caleg DPR RI, dari Partai Kebangkitan Bangsa (PKB), Dapil Jateng 8, No Urut 4. Caleg tersebut lolos dalam DCT padahal la masih berstatus sebagai PNS aktif. Panwaslu Kabupaten Banyumas menilai bahwa: "Terkait dengan lolosnya Sdr. Muhyi Fadlil dalam Daftar Calon Tetap (DCT) calon anggota DPR RI, sementara yang bersangkutan belum pernah mengajukan permohononan berhenti sebagai PNS, maka Panwaslu Kabupaten Banyumas beranggapan:

"adanya dugaan pelanggaran pidana pemilu penggunaan dokumen yang dipalsukan, yang dilakukan oleh Sdr. Muhyi Fadlil, S.Pd. Dalam Pasal 266, Undang-undang Nomor 10 Tahun 2008 tentang pemilihan Umum Aggota Dewan Perwakilan Rakyat, Dewan Perwakilan Daerah dan Dewan Perwakilan Rakyat Daerah, disebutkan bahwa: "Setiap orang yang dengan sengaja membuat surat atau dokumen dengan maksud untuk memakai atau menyuruh orang memakai, atau 
setiap orang yang dengan sengaja menggunakan surat atau dokumen yang dipalsukan untuk menjadi bakal calon anggota DPR, DPD, DPRD Provinsi, DPRD Kabupaten/Kota atau calon Peserta Pemilu sebagaimana dimaksud dalam Pasal 63 dan dalam Pasal 73, dipidana dengan pidana penjara paling singkat 36 (tiga puluh enam) bulan dan paling lama 72 (tujuh puluh dua) bulan dan denda paling sedikit Rp. 36.000.000,00- Rp. 72.000.000,00 (tujuh puluh dua juta rupiah)".

Berdasarkan hasil kajian tersebut, pada tanggal 27 Maret 2009 Panwaslu Kabupaten Banyumas, mengirimkan rekomendasi ke Bawaslu dengan Surat Nomor 62/Panwaslu/III/2009. Panwaslu Kabupaten Banyumas meminta kepada Bawaslu untuk segera menindaklanjuti temuan tersebut, sesuai dengan peraturan perundang-undangan yang berlaku. Namun demikian, sampai dengan hari pelaksanaan Pemungutan Suara, 8 April 2009, Bawaslu tidak memberikan tanggapan apa pun atas rekomendasi Panwaslu Kabupaten Banyumas. Pada hari tersebut, Muhyi Fadlil, S.Pd juga masih tercantum dalam DCT dan berhak untuk dipilih.

Keenam, kampanye dan dana kampanye, dugaan pelanggaran pidana pemilu yang terjadi pada masa kampanye Pemilu DPR, DPD, DPRD 2009 di Kabupaten Banyumas, berkaitan dengan pelanggaran jadwal kampanye (kampanye di luar jadwal), politik uang, anggota BPD sebagai pelaksana kampanye, PNS terlibat dalam kampanye, perusakan alat peraga kampanye, pemaksaan untuk memilih caleg tertentu, penggunaan fasilitas negara untuk kampanye, dan kampanye di tempat ibadah dan tempat pendidikan. Dugaan Pelanggaran Pidana Pemilu pada masa kampanye Pemilu DPR, DPD, DPRD tahun 2009 tidak seluruhnya ditangani oleh Panwaslu di tingkat Kabupaten Banyumas. Seperti diinformasikan pada tabel di atas, sejumlah dugaan pelanggaran ditangani langsung oleh Panwaslu Kecamatan. Namun demikian, ada beberapa kasus yang sebelumnya sudah ditangani oleh Panwaslu Kecamatan, kemudian dilimpahkan ke Panwaslu Kabupaten untuk ditangani lebih lanjut. Laporan dugaan Pelanggaran Pi- dana Pemilu berupa kampanye di luar jadwal oleh Sitam Sumiardi dan Subur Priyanto, di rumah Bpk. Sahroni RT 07/RW 04 Desa Kedunggede, Kec. Lumbir pada tanggal 4 Februari 2009 di Grumbul Cimapag, Desa Kedunggede Kecamatan Lumbir, telah dilaporkan oleh Tojo Sukmono, tanggal 4 Februari 2009, melalui Panwaslu Kecamatan Lumbir pada tanggal 5 Februari 2009. Terhadap kasus ini, Panwaslu Kecamatan Lumbir telah melakukan klarifikasi terhadap para pihak (pelapor, terlapor, dan saksi). Namun demikian, pada tanggal 8 Februari 2009, kasus ini dilimpahkan ke Panwaslu Kabupaten Banyumas. Karena batas waktu kadaluarsa kasus ini tinggal tinggal satu (1) hari, maka pada tanggal 9 Februari 2009, Panwaslu Kabupaten Banyumas melakukan klarifikasi pada para pihak (pelapor, terlapor, dan saksi). Pada acara klarifikasi hadir pula personel Sentra Gakkumdu dari Polres Banyumas, sengaja hadir untuk mendengarkan keterangan para pihak yang diklarifikasi. Dengan demikian mereka sudah langsung bisa menarik kesimpulan sementara apakah kasus tersebut dapat ditindaklanjuti ke proses penyidikan kepolisian atau tidak. Berdasarkan hasil klarifikasi dan kajian yang dilakukan oleh Panwaslu Kabupaten Banyumas, kasus yang dilaporkan Sdr. Tojo Sukmono merupakan Pelanggaran Pidana Pemilu, sehingga kasus tersebut pada hari itu juga di teruskan ke Polres Banyumas. Kasus Pelanggaran Pidana Pemilu berupa kampanye di luar jadwal yang dilakukan oleh Sitam Sumiardi dan Subur Priyanto, selanjutnya disidangkan di Pengadilan Negeri Purwokerto. Berdasarkan Putusan Pengadilan Negeri Purwokerto Nomor: 01/Pid.S/2009/PN.Pwt.

Berdasarkan permohonan banding dari Jaksa Penuntut Umum atas Putusan Pengadilan Negeri Purwokerto tersebut, Pengadilan Tinggi Semarang, Putusan Nomor: 97/PID/2009/PT. SMG, 16 Maret 2009. Dugaan Pelanggaran Pidana Pemilu karena mengganggu jalannya kampanye, telah dilaporkan oleh Sitam Sumiardi dan Subur Priyanto, dengan No. laporan: 05/Lap/ Panwaslu/II/2009. Mereka melaporkan Sdr. Tojo Sukmono pada kegiatan kampanye caleg PDP yang bertempat di rumah Bpk. Sahroni RT 
07/RW 04, Grumbul Cimapag, Desa Kedunggede, Kec. Lumbir, tanggal 4 Februari 2009. Kasus ini sebelumnya juga telah ditangani oleh Panwaslu Kecamatan Lumbir, dengan melakukan klarifikasi pada para pihak (pelapor, terlapor, dan saksi). Namun, kasus tersebut kemudian dilimpahkan ke Panwaslu Kabupaten Banyumas untuk ditindaklanjuti. Menindaklanjuti laporan pelanggaran tersebut, pada tanggal 9 Februari 2009, Panwaslu melakukan klarifikasi terhadap para pihak (pelapor, terlapor, dan saksi). Berdasarkan hasil klarifikasi dan kajian yang dibuat oleh Panwaslu Kabupaten Banyumas, maka dalam rapat pleno Panwaslu Kabupaten Banyumas laporan tersebut dinyatakan batal demi hukum dan tidak dapat ditindaklanjuti. Karena, kegiatan kampanye yang di selenggarakan oleh Sitam Sumiardi dan Subur Priyanto, merupakan kegiatan kampanye yang dilakukan di luar jadwal waktu.yang ditetapkan oleh KPU Kabupaten Banyumas dan KPU Provinsi Jawa Tengah. Kegiatan tersebut juga tidak memiliki STTP dari kepolisian. Tanggal 21 Februari 2009, Andy Harsono (PPL Kecamatan Wangon) melalui Panwaslu Kecamatan Wangon melaporkan PAC Partai Gerindra, Bambang Priyono (Penasehat Partai Gerindra Kab. Banyumas), Sadar Subagyo, (Caleg DPR RI Partai Gerindra DP Jateng VIII) dan Tri Mulyono, B.A, Caleg DPRD Kabupaten Banyumas dari DP Banyumas I, dengan No. Laporan 011/Lap/Panwaslu/II/2009 tentang Kampanye diluar jadwal pada acara silaturahmi yang diselenggarakan oleh Pimpinan Anak Cabang (PAC) Partai Gerindra kecamatan Wangon pada hari Sabtu, 21. Februari 2009 di rumah Bapak Seno RT 01/IX, Karangtengah, Desa Jambu, Keamatan Wangon. Laporan tersebut, oleh Panwaslu Kecamatan Wangon dilimpahkan ke Panwaslu Kabupaten Banyumas untuk ditindaklanjuti. Menindaklanjuti kasus tersebut, pada tanggal 25 Februari 2009, Panwaslu Kabupaten Banyumas memanggil Sdr. Andy Harsono (PPL Desa Jambu) selaku pelapor dan Sdr. Timbul, S.Pd dan Sdr. Mukharom, S.Pd (Anggota dan Ketua Panwaslucam Wangon) sebagai saksi pelapor. Acara klarifikasi tersebut juga dihadiri oleh personel Sentra Gakkumdu Polres Banyumas. Berdasarkan hasil klarifiksi dan kajian yang dibuat oleh Panwaslu Kabupaten Banyumas, laporan tersebut dinyatakan sebagai tindak Pidana Pelanggaran Pemilu, dan diteruskan ke Polres Banyumas pada tanggal 25 Februari 2009. Selanjutnya laporan tersebut disidangkan di Pengadilan Negeri Purwokerto. berdasarkan Putusan Pengadilan Negeri Purwokerto Nomor: 02/Pid.S/ 2009/PN.Pwt, tanggal 23 Maret 2009.

Bahwa dengan mendasarkan kepada ketentuan Pasal 1 ayat (2) KUHP, terhadap perbuatan Terdakwa a quo harus diberlakukan peraturan yang menguntungkan bagi terdakwa, yaitu harus diberlakukan Keputusan KPU Kabupaten Banyumas Nomor 13/PEMILU/2009, tanggal 13 Maret 2009, dengan ukuran peraturan yang baru tersebut, perbuatan terdakwa melakukan kampanye tertutup/terbatas dibolehkan di setiap waktu dan di setiap tempat, dengan demikian tidak ada pelanggaran jadwal dan tempat kampanye tertutup/terbatas yang dilakukan oleh terdakwa; bahwa karena tidak ada pelanggaran jadwal dan tempat kampanye yang dilanggar oleh terdakwa, maka tidak ada tindak pidana sebagaimana yang diancamkan kepada Terdakwa dalam Pasal 269 UU Nomor 10 tahun 2008.

Tanggal 19 Februari 2009, Waluyo Wijanarko, dengan laporan Nomor 08/Lap/Panwaslu/II/2009, melaporkan Yudi Rahmanto, Caleg dari Partai Golkar, Dapil Banyumas IV, atas dugaan pelanggaran Pemilu yang dilakukan Yudi Rachmanto, yaitu memaksa warga RW 1 Pasir Muncang untuk memilih yang bersangkutan sebagai Caleg DPRD di Dapil Banyumas IV, pada tanggal 10 Februari 2009. Melalui rapat pleno Panwaslu Kabupaten Banyumas, laporan tersebut dinyatakan kadaluwarsa dan tidak dapat ditindaklanjuti. Dugaan Pidana Pemilu di laporkan oleh Sdr. Darmanto, tanggal 24 Februari 2009, dengan laporan Nomor: 10/Lap/ Panwaslu/II/2009, tentang pembagian uang yang dilakukan Tim sukses Syahril, S.E., (Caleg DPR RI dari Partai Hanura), sesaat setelah selesai acara pertemuan di Hotel Astro Sokaraja, tanggal 21 Februa10/Lap/Panwaslu/ II/2009ri 2009. Berdasarkan tanggal kejadian peristiwa dan tanggal pelaporan kasus tersebut, 
melalui rapat pleno Panwaslu Kabupaten Banyumas pelaporan Sdr. Darmanto dinyatakan kadaluwarsa dan tidak dapat ditindaklanjuti.

Pelaporan sdr. H. Arsuni Lukman Effendi, tanggal 15 April 2009, tentang Pelanggaran hukum yang dilakukan oleh sdr. Subagyo, S.Pd., Caleg DPRD Kabupaten Banyumas, Dapil II, Partai Demokrasi Indonesia Perjuangan (PDI P). Yang bersangkutan dilaporkan, berkaitan dengan status Subagyo, S.Pd, pada saat mengajukan persyaratan pencalonannya sebagai calon anggota DPRD Kabupaten Banyumas masih berstatus sebagai anggota Badan Permusyawaratan Desa (BPD). Dengan statusnya, Subagyo, S.Pd., seharusnya tidak boleh melakukan kampanye. Panwaslu Kabupaten Banyumas, sebelumnya telah mendapatkan pengaduan melalui surat tanpa identitas (surat kaleng) tentang permasalahan tersebut. Pelaporan melalui surat atas nama semua caleg Dapil Banyumas II, tanggal 13 Maret 2009, tentang laporan pelanggaran yang dilakukan oleh Subagyo, S.Pd, yang tetap mencalonkan menjadi caleg padahal belum mengundurkan diri jadi Anggota BPD, Desa Kedungwringin, Kecamatan Jatilawang. Atas laporan tersebut, walaupun pengaduan tidak disertai dengan identitas, namun karena semua anggota Panwaslu mengenal pihak terlapor, Panwaslu Kabupaten Banyumas, memanggil terlapor untuk diklarifikasi. Yang bersangkuan menyatakan telah mengundurkan diri sebagai anggota BPD Desa Kedungwringin, Kecamatan Jatilawang, sejak tanggal 28 Agustus 2008, dengan menunjukkan surat pengunduran dirinya. Dengan dasar tersebut, laporan Sdr. Arsuni Lukman Efendi, oleh Panwaslu Kabupaten Banyumas dinyatakan tidak cukup bukti dan tidak dapat ditindaklanjuti.

Penyelenggaraan Sosialisasi Tata Cara Pencontrengan Pemilu 2009 di Kelurahan Purwokerto Kidul dilakukan oleh Caleg $\mathrm{Hj}$. Siti Rochaeny, SH (Caleg DPRD Provinsi Jawa Tengah, dari Partai Golkar, Dapil Jateng 8) dan Yudi Rachmanto, SE. (Caleg DPRD Kabupaten Banyumas, dari Partai Golkar, Dapil Banyumas IV). Kasus yang dilimpahkan dari Panwaslu Kecamatan Purwokerto tersebut, sebenarnya memenuhi unsur Pelanggaran Pidana Pemilu, yaitu berupa kampanye di luar jadwal waktu yang ditetapkan oleh KPU Kabupaten Banyumas. Namun demikian, kasus tersebut terlambat di limpahkan sehingga tidak dapat ditindaklanjuti karena melebihi batas waktu yang ditentukan oleh undang-undang (kadaluwarsa).

Dugaan Pelanggaran Pidana Pemilu, berupa pencabutan alat peraga kampanye, dilaporkan tanggal 17 Februari 2009, oleh Sdr. Tjaroko Wibowo. Pelapor melaporkan Sdr.Rakit, Sukur dan kawan-kawan dengan Nomor laporan: 07/ Lap/Panwaslu/II/2009, atas pencabutan Spanduk dr. Budi Setyawan (Caleg DPRD Kabupaten Banyumas, dari PDI P, Dapil Banyumas IV), di Jalan Gereja, pada tanggal 6 Februari 2009. Atas dasar tanggal kejadian peristiwa dan tanggal pelaporan, oleh Panwaslu Kabupaten Banyumas melalui rapat plenonya, laporan Sdr. Tjaroko Wibowo dinyatakan kadaluwarsa dan tidak dapat ditindaklanjuti.

Dugaan Pelanggaran Pidana Pemilu, berupa pengrusakan alat peraga kampanye juga dilaporkan oleh Sdr. Warsito, tanggal 24 Februari 2009. Pelapor melaporkan tentang adanya perusakan baliho atas nama Juli Krisdiyanto, SE (Caleg DPRD Kabupaten Banyumas, dari PDI P, Dapil Banyumas V, No. urut 1), di sepanjang Jalan Raya Tambak-Sumpiuh Kabupaten Banyumas. Laporan tersebut oleh Panwaslu Kabupaten Banyumas dinyatakan tidak dapat ditindaklanjuti karena tidak cukup bukti. Laporan tidak disertai saksi-saksi yang melihat kejadian dan waktu terjadinya pelanggaran tersebut.

Dugaan Pelanggaran Pidana Pemilu, berupa pengrusakan alat peraga kampanye juga di laporkan oleh Sdr. Arif Supangat, tanggal 27 Januari 2009, dengan laporan Nomor: 02a./Panwaslu/I/2009. Pelapor melaporkan adanya pencurian dan pengrusakan Baliho $\mathrm{Hj}$. Farida Syamsi Chadaria, SH, MH (Caleg DPR RI, dari Partai Golkar, Dapil Jateng 8, No Urut 1). Laporan tersebut oleh Panwaslu Kabupaten Banyumas dinyatakan tidak dapat ditindaklanjuti karena tidak cukup bukti. Laporan tidak di sertai saksi-saksi yang melihat kejadian dan waktu terjadinya pelanggaran tersebut.

Dugaan Pelanggaran Pidana Pemilu, berupa kampanye di tempat pendidikan dilaporkan 
oleh Tri Joko Wahyono, tanggal 01 April 2009, dengan nomor laporan:15/Lap/Panwaslu/III/ 2009. Pelapor melaporkan tim sukses Fardan Fauzan, BA, M.Sc (Caleg DPR RI, dari Partai Demokrat, Dapil Jaten 8). Pelapor melaporkan tentang alat peraga kampanye berupa surat edaran dan leaflet yang disertai visi dan misi Fardan Fauzan BA, M.Sc, sebagai caleg yang di kirim via pos ke SMAN 3 Purwokerto. Panwaslu Kabupaten Banyumas menindaklanjuti laporan tersebut, dengan memanggil pelapor (Tri Joko Wahyono), saksi pelapor Toto Budi Wibowo (Satpam SMUN 3), terlapor (tim sukses Fardan Fauzan: Trisno (bagian logistik) dan Aris) untuk diklarifikasi pada tanggal 3 April 2009. Berdasarkan hasil klarifikasi, tim sukses yang di panggil menyatakan tidak tahu menahu atas kasus tersebut. Karena yang bersangkutan tidak pernah melakukan model kampanye seperti yang didakwakan. Mereka juga menyatakan bahwa tanda tangan yang ada di surat pengantar pengiriman alat peraga kampanye di sekolah, bukan tanda tangan Fardan Fauzan, tetapi hanya merupakan hasil scan. Panwaslu Kabupaten Banyumas akhirnya tidak meneruskan kasus tersebut karena tidak cukup bukti. Fardan Fauzan yang dipanggil untuk diklarifikasi tidak hadir hingga batas waktu yang ditentukan oleh undang-undang berakhir (kadaluwarsa).

Dugaan Pelanggaran Pidana Pemilu berupa politik uang, dilaporkan oleh warga karang taruna, Kelurahan Karangklesem, Purwokerto Selatan, yang dikirimkan via Pos, tanggal $8 \mathrm{Ap}$ ril 2009. Pelapor melaporkan Yudi Rachmanto (caleg DPRD Kabupaten Banyumas, dari Partai Golkar, Dapil Banyumas IV), yang diduga telah melakukan money politic yaitu memanipulasi bantuan pemerintahan, membuat laporan fiktif, melakukan ancaman kepada warga, dan membagikan uang kepada warga agar memilih Yudi Rachmanto, SE, pada tanggal 31 Maret 2009. Melalui rapat pleno Panwaslu Kabupaten Banyumas, laporan tersebut dinyatakan kadaluwarrsa, tidak cukup bukti, pelapor tidak jelas, sehingga tidak dapat ditindaklanjuti.

Dugaan pelanggaran yang dapat dikategorikan dalam Pelanggaran Pidana Pemilu adalah kampanye yang dilakukan pada masa kick off (masa tenang sebelum pelaksanaan kampanye rapat umum, yang ditetapkan oleh KPU untuk tidak melakukan kegiatan kampanye rapat umum). Kampanye keliling wilayah Kec. Kebasen di 12 desa partai PDK di wilayah Kebasen Dapil II (Caleg H.Arsuni Lukman Effendi, tanggal 16 Maret 2009 yaitu pada masa kick off). Demikian juga Kampanye Pawai Becak dan Andong dan Orasi Partai Matahari Bangsa di Desa Sawangan, Kalisalak, Kecamatan Kebasen, tanggal 16 Maret 2009. Menindaklanjuti laporan pelanggaran oleh tersebut, Panwaslu Kabupaten Banyumas berkoordinasi dengan Panwaslu Kecamatan di berbagai wilayah untuk menertibkan dan menghentikan kegiatan tersebut.

Ketujuh, masa tenang, sejumlah dugaan Pelanggaran Pidana Pemilu yang terjadi pada masa tenang Pemilu DPR, DPD, DPRD 2009 di Kabupaten Banyumas telah dilaporkan ke Kantor Panwaslu Kabupaten Banyumas. Dugaan Pelanggaran Pidana Pemilu seluruhnya berkaitan dengan dugaan politik uang, sebagaimana diinformasikan pada Tabel 10 berikut ini:

Dugaan Pelanggaran Pidana Pemilu, berupa politik uang dilaporkan oleh Winarsi, S.Ag (PPL Desa Pengadegan). Pelapor melaporkan dugaan politik uang yang dilakukan oleh Soetrisno (Caleg DPRD Kabupaten Banyumas, dari PKS, Dapil Banyumas I), yang berasal dari Desa Parungkamal Kecamatan Lumbir, dengan memberikan 2 Genzet, pada warga masyrakat Grumbul Sawiara, Desa Pengadegan, Kecamatan Wangon. Atas laporan tersebut, Panwaslu Kabupaten Banyumas memerintahkan Panwaslu Kecamatan Wangon untuk menindaklanjuti laporan tersebut. Namun demikian, kasus tersebut akhirnya dilimpahkan ke Panwaslu Kabupaten Banyumas. Menindaklanjuti hal tersebut, pada tanggal 7 April 2009, Panwaslu Kabupaten Banyumas melakukan klarifikasi yang dilakukan di Kantor Panwaslu Kecamatan Wangon, agar lebih mendekatkan dengan domisili para pihak yang hendak diklarifikasi. Hadir pada acara klarifikasi tersebut: Slamet (tim sukses terlapor), Mukidin (tim sukses terlapor), Rosidin (tim sukses terlapor) dan didampingi Kadus Sawiara yaitu Sartiman. Dari keterangan yang mereka berikan selama proses klarifikasi, bahwa 2 
genzet yang diduga pemberian dari Soetrisno, adalah dibeli dengan swadaya warga masyarakat sendiri. Karena masyarakat di grumbul tersebut, setiap tahun selalu dihadapkan pada masalah kekurangan air. Masih belum puas dengan hasil klarifikasi tersebut, PPL Desa Pengadegan diminta untuk mencari informasi yang lain. Namun berdasarkan laporannya, semua warga di grumbul tersebut seolah-olah tutup mulut ketika dimintai keterangan perihal genzet tersebut. Akhirnya, Panwaslu Kabupaten Banyumas tidak meneruskan kasus tersebut, karena tidak cukup bukti.

Dugaan Pelanggaran Pidana Pemilu berupa politik uang, juga dilaporkan ole Sdr. Kasidi, tanggal 5 dan 6 April 2009, dengan laporan Nomor: 27/Lap/Panwaslu/IV/2009. Kasidi melaporkan Meli, Nanang, Rohmat, Ibu Masroh dan Ibu Rusmini atas dugaan memberikan uang kepada warga untuk memilih caleg $\mathrm{H}$. Arsuni Lukman Effendi (Caleg DPRD Kabupaten Banyumas, dari PDK, Dapil Banyumas II). Kasus tersebut ditindaklanjuti oleh Panwaslu Kecamatan Jatilawang, dengan melakukan klarifikasi para pihak: pelapor, terlapor dan saksi. Namun akhirnya kasus tersebut tidak diteruskan karena tidak cukup bukti.

Dugaan pelanggaran politik uang yang terjadi pada masa tenang telah dilaporkan oleh, Purwanto Nugroho, tanggal 11 April 2009, dengan laporan Nomor: 19/Lap/Panwaslu/IV/ 2009. Purwanto Nugroho melaporkan Sdr. Kadir karena yang bersangkutan telah membagibagikan uang ke warga masyarakat pada tanggal 8 April 2009, agar memilih caleg Ir. Nur Zaman (Caleg DPRD II Dapil 1 Partai Amanat Nasional). Menindaklanjuti laporan tersebut, Panwaslu Kabupaten Banyumas memanggil para pihak untuk diklarifikasi pada tanggal tanggal 14 April 2009. Klarifikasi dilakukan di Kantor Panwaslu Kabupaten Banyumas, dihadiri oleh Purwanto Nugroho (pelapor), Ito, Dirin, dan Sukamto (saksi), Kadir (terlapor). Belum puas dengan hasil klarifikasi yang dilakukan pada tanggal 14 April 2009, pada tanggal 15 April 2009, Panwaslu Kabupaten Banyumas, kembali melakukan klarifikasi. Kali ini klarifikasi dilakukan di Kantor Panwaslu Kecamatan Wangon, agar lebih mendekatkan dengan domisili para pihak. Hadir pada acara tersebut, Supriyo Sunaryo, Rusmi Efendi, Hadi SP, dan Supriyadi (sebagai saksi). Namun demikian, dugaan politik uang tersebut sangat sulit dibuktikan. Akhirnya, melalui rapat pleno Panwaslu Kabupaten Banyumas, kasus tersebut dinyatakan tidak dapat diteruskan karena tidak cukup bukti.

Dugaan pelanggaran Pemilu berupa politik uang yang terjadi pada masa tenang Pemilu DPR, DPD, DPRD tahun 2009 juga dilaporkan oleh M.A. Hidayat, tanggal 13 April 2009, dengan laporan Nomor: 21/Lap/Panwaslu/IV/ 2009. Pelapor melaporkan Yusron, Warga RT 01/RW 04 Desa Sawangan Kecamatan (Ketua RT 01dan tim sukses Caleg Nur Samsi dari PPP No urut 5 Dapil 2 Banyumas), bahwa terlapor telah memberikan uang kepada saksi yang dititipkan ibunya (Lasiem) untuk memilih Nur Samsi caleg dari PPP tersebut, pada tanggal 5 dan 6 April 2009. Panwaslu Kabupaten Banyumas, melalui rapat pleno menyatakan bahwa laporan M.A. Hidayat kadalursa dan tidak dapat ditindaklanjuti.

Dugaan politik uang pada masa tenang juga dilaporkan oleh Sdr. Sungaib pada tanggal 8 April 2009, dengan laporan Nomor: 23/Lap/ Panwaslu/IV/2009. Sungaib melaporkan Arif Fauzan Sardi, Surtini dan Hadi Kusmiarto Sarkim (Tim Sukses Caleg Fardilla Tri Astuti, S.Kom), yang telah membagi-bagikan uang kepada warga Desa Beji, Kecamatan Kedungbanteng, agar pada tanggal 9 April 2009 mencontreng Fardilla Tri Astuti, S.Kom (Caleg DPRD Kabupaten Banyumas, dari PAN, Dapil Banyumas 3). Sebelumnya kasus tersebut telah ditangani oleh Panwaslu Kecamatan Kedungbanteng, namun takut terjadi serangan masa yang begitu banyak dari kader PDI P, maka kasus tersebut dilimpahkan ke Panwaslu Kabupaten Banyumas. Hari itu juga Panwaslu Kabupaten Banyumas, melakukan klarifikasi pada para pihak: Sungaib (pelapor), Arif Fauzan Sardi, Surtini dan Hadi Kusmiarto Sarkim (terlapor), dan saksi (Hendi, Hadi Suwito, Tarsun, Sutinah, Suharyanto). Dalam klarifikasi diperoleh keterangan dari para terlapor, bahwa mereka me- 
mang membagi-bagikan uang ke warga, agar mencontreng Fardilla Tri Astuti, S.Kom, pada tanggal 9 April 2009. Mereka juga menyatakan bahwa, sebelumnya melakukan pendataan terhadap warga yang akan diberi uang. Semua saksi yang dipanggil menguatkan dugaan tersebut. Namun demikian, para terlapor bukanlah tim kampanye yang didaftarkan ke KPU. Mereka hanya warga biasa yang diminta bantuannya. Personel Sentra Gakkumdu dari Polres Banyumas yang juga hadir pada acara tersebut, sudah menarik kesimpulan bahwa kasus tidak dapat diteruskan ke kepolisian. Acara klarifikasi yang dilakukan di Kantor Panwaslu Kabupaten Banyumas tersebut, tersebut dihadiri oleh puluhan kader PDI P, dan untuk menjaga agar tidak terjadi hal-hal yang tidak diinginkan, Polres Banyumas menerjunkan 1 (satu) pleton aparat kepolisian untuk mengamankan acara tersebut. Sekalipun terlapor mengakui, keterangan saksi menguatkan, dan terdapat barang bukti uang sebanyak Rp. 1.105.000,- (satu juta seratus lima rupiah), namun akhirnya kasus tersebut tidak dapat diteruskan ke Polres Banyumas. Jaksa dan Polisi tetap berpedoman bahwa yang dapat dijerat adalah mereka yang terdaftar sebagai pelaksana kampanye di KPU.

Dugaan politik uang yang terjadi di masa tenang juga dilaporkan oleh Rahmanto (warga Kecamatan Karanglewas) via Pos tanggal 11 April 2009, dengan laporan Nomor: 24/Lap/Panwaslu/IV/2009. Rahmanto melaporkan Kadirin, Warno, Narto, dan Imam Partono dalam surat yang tidak jelas menyebutkan perihal money politic yang dilakukan pada masa tenang. Oleh karenanya, Panwaslu Kabupaten Banyumas tidak menindaklanjuti laporan tersebut. Sebelumnya Panwaslu Kabupaten Banyumas telah memerintahkan Panwaslu Kecamatan untuk mencek kebenaran laporan tersebut. Namun tidak ditemukan tentang peristiwa yang dilaporkan.

Pelaporan tentang dugaan politik uang yang tidak jelas juga datang dari Saefudin, tanggal 11 April 2009 (via Pos). Saefudin melaporkan Caleg DPRD dari Partai PKB yang berada di DAPIL II Banyumas (tidak disebutkan namanya) yang menjanjikan akan memberikan uang sebesar Rp. 50.000 .000 kepada 3 org yaitu sdr. Sugeng Rt 03/06, sdr Widi Rt 02/07 dan sdr Gendu Rt 02/07 semuanya warga Desa Tipar Kec. Rawalo. Panwaslu Kabupaten Banyumas memerintahkan Panwaslu Kecamatan untuk menindaklanjuti laporan tersebut. Namun demikian, setelah dilakukan penelitian di lokasi yang dimaksud, nama-nama tersebut tidak ada. Dengan demikian, laporan tersebut tidak dapat di teruskan karena tidak cukup bukti. Pada akhirnya, tidak satu pun dugaan pelanggaran politik uang yang dapat diteruskan ke ranah hukum.

Kedelapan, perlengkapan pemungutan suara, sekalipun banyak permasalahan yang berkaitan dengan perlengkapan pemungutan suara, Pada Pemilu DPR, DPD, DPRD tahun 2009, di Kabupaten Banyumas, namun Panwaslu Kabupaten Banyumas tidak memperoleh temuan dan menerima laporan Pelanggaran Pidana Pemilu yang berkaitan dengan perlengkapan pemungutan suara (logistik Pemilu).

Kesembilan, pemungutan dan penghitungan suara, pada tahapan pemungutan dan penghitungan suara Pemilu DPR, DPD, DPRD tahun 2009, Di Kabupaten Banyumas, terdapat 2 (dua) laporan kasus dugaan Pelanggaran Pidana Pemilu. Laporan dugaan pelanggaran politik uang, telah dilaporkan Anggi Pamungkas, tanggal 9 April 2009, dengan Nomor:17/Lap/Panwaslu/IV/2009. Ia melaporkan Andi (tim sukses) Ika Yuli Setyarini yang telah membagikan uang kepada masyarakat di RT 01 RW 07 Purwokerto Timur disertai dengan ajakan untuk memilih caleg yang bersangkutan. Tindak lanjut Panwaslu Kabupaten Banyumas terhadap laporan tersebut adalah mengundang pelapor, terlapor, dan saksi (Bp. Salim dan Ibu Tari) untuk diklarifikasi. Namun demikian, hingga 2 (dua) kali panggilan dilakukan, pihak terlapor tidak hadir dalam klarifikasi hingga batas waktu yang di tentukan (kasus dinyatakan kadaluwarsa). Melalui rapat pleno Panwaslu Kabupaten Banyumas, kasus tersebut dinyatakan tidak dapat ditindaklanjuti karena tidak cukup bukti.

Dugaan pelanggaran politik uang yang dilakukan oleh Sdr. Andi (tim sukses) Ika Yuli Setyarini juga dilaporkan oleh Teguh Yulianto, pada tanggal 9 April 2009, melalui laporan No- 
mor: 18/Lap/Panwaslu/IV/2009. Andi dilaporkan telah membagikan uang kepada masyarakat di Kebondalem RT 4/ RW 6 Purwokerto Timur disertai dengan ajakan untuk memilih caleg yang bersangkutan pada tanggal 9 April 2009. Terhadap kasus tersebut, Panwaslu Kabupaten Banyumas menindaklanjti dengan memanggil para pihak (pelapor, terlapor, dan saksi (lbu Paryah dan Ibu Dasimi) untuk diklarifikasi. Sama dengan kasus yang dilaporkan oleh Sdr. Anggi Pamungkas, kasus tersebut tidak dapat ditindaklanjuti karena tidak cukup bukti. Hingga batas waktu yang ditentukan, pelapor tidak hadir memenuhi undangan klarifikasi.

Kesepuluh, rekapitulasi hasil penghitungan suara, sekalipun pelaksanaan tahapan rekapitulasi hasil penghitungan suara pada Pemilu DPR, DPD, DPRD 2009 di Kabupaten Banyumas mengalami keterlambatan sejak rekapitulasi di tingkat kecamatan (PPK), hingga tingkat kabupaten (KPU), namun Panwaslu Kabupaten Banyumas tidak menemukan dan menerima adanya dugaan Pelanggaran Pidana Pemilu yang terjadi pada tahapan ini.

Kesebelas, penetapan hasil pemilu, berdasarkan hasil pengawasan yang dilakukan terhadap proses Penetapan Hasil Pemilu DPR, DPD, DPRD tahun 2009, Panwaslu Kabupaten Banyumas tidak menemukan atau pun menerima dugaan Pelanggaran Pidana Pemilu yang berkaitan dengan proses penetapan hasil Pemilu di Kabupaten Banyumas.

Keduabelas, pengucapan sumpah/janji anggota DPR, DPD dan DPRD. Berdasarkan hasil pengawasan yang dilakukan terhadap pelaksanaan Pengucapan Sumpah/Janji Anggota DPR, DPD dan DPRD, hasil Pemilu 2009, Panwaslu Kabupaten Banyumas tidak menemukan atau pun menerima dugaan Pelanggaran Pidana Pemilu yang berkaitan dengan pelaksanaan Pengucapan Sumpah/Janji Anggota DPR, DPD dan DPRD, hasil Pemilu 2009 di Kabupaten Banyumas.

\section{Pelanggaran Pemilu dan Penangananya di Kabupaten Purbalingga}

Pertama, pendaftaran peserta pemilu. bersamaan dengan penetapan peserta pemilu
Panwaslu tidak mengikuti proses verifikasi faktual pendaftaran peserta pemilu, karena Panwaslu belum terbentuk. Sehingga dalam proses pendaftaran Peserta pemilu di Kabupaten Purbalingga, Panwaslu se kabupaten Purbalingga tidak menemukan dan tidak mendapatkan laporan tentang tindak pidana pemilu. Pada veryfikasi faktual calon anggota DPD juga Panwaslu tidak menemukan tindak pidana pemilu. Sehingga pada proses tahapan pendaftaran peserta pemilu nyaris Panwaslu kabupaten Purbalingga tidak menemukan dan tidak mendapatkan laporan tindak pidana pemilu.

Kedua, penetapan peserta pemilu. Dalam proses penetapan peserta pemilu Panwaslu belum terbentuk, sehingga proses ini dilalui oleh KPU dengan tanpa pengawasan oleh Pengawas Pemilu. Sampai batas akhir penetapan Peserta pemilu oleh KPU, Panwaslu hanya mendapatkan salinan dari penetapan Peserta Pemilu di Kabupaten Purbalingga untuk diawasi proses pelaksanaan kampanyenya saja. Hasilnya bahwa pada proses penetapan peserta pemilu, Panwaslu tidak mendapatkan laporan dan tidak menemukan tindak pidana pemilu baik yang dilakukan oleh KPU, maupun lembaga lain secara struktural.

Ketiga, penetapan jumlah kursi dan daerah pemilihan. Pada proses penetapan jumlah kursi per Daerah pemilihan (Dapil) Panwaslu mengadakan pengawasan mutlak ke KPU yang menentukan jumlah kursi pada dapil sesuai jumlah penduduk dan jumlah pemilih pada dapil yang ditentukan. Proses ini Panwaslu se kabupaten Purbalingga tidak menemukan dan tidak mendapatkan laporan pelanggaran Pidana oleh KPU dan lembaga strukural lain. Sehingga proses penentuan kursi pada dapil yang terbagi menjadi 5 daerah pemilihan (dapil) berjalan secara prosedural menurut pengawasan Panwaslu Kabupaten Purbalingga.

Keempat, pencalonan anggota DPR, DPD dan DPRD. Pada pencalonan anggota DPR, DPD dan DPRD Provinsi, Panwaslu tidak juga menemukan tindak pidana pemilu, karena di samping sedikitnya calon anggota DPR yang dari Purbalingga juga karena proses verifikasi calon anggota DPR juga Panwaslu tidak ikut meng- 
awasi karena belum terbentuk. Lain lagi dengan proses pencalonan Anggota DPRD kabupaten Purbalingga, pada saat penetapan calon anggota DPRD Kabupaten Purbalingga pada tanggal 31 Oktober 2008, bersamaan dengan rapat pleno penetapan Calon anggota DPRD kabupaten Purbalingga. Apa yang terjadi dalam proses penetapan tersebut nyaris tidak diawasi, baik mulai dari pendaftaran, verifikasi administrasi dan verifikasi faktual sampai pada penetapan calon anggota DPRD Kabupaten Purbalingga. Dalam hal ini Panwaslu tidak menemukan tindak pidana pemilu dalam tahapan penetapan calon anggota legislatif.

Kelima, kampanye dan dana kampanye. Dalam tahapan kampanye pemilu legislatif 2009, Panwaslu mendapatkan beberapa temuan dan laporan pelanggaran tindak pidana pemilu, namun hanya satu kasus saja yang bisa di teruskan sampai dengan pengadilan dan memperoleh putusan yang berkekuatan hukum tetap yaitu kasus pengrusakan alat peraga kampanye oleh saudara Sulino di desa Onje Kecamatan Mrebet pada tanggal 28 Pebuari 2008. Kasus ini disidangkan diputus oleh Pengadilan Negeri Kabupaten Purbalingga dengan perkara pidana Nomor: 01/Pid.S/2009/PN.Pbg yang amar putusannya menyatakan bersalah saudara Sulino dan dihukum dengan pidana penjara selama 6 (enam) bulan dan denda sebesar Rp. 6.000. 000,00 (enam juta rupiah) dengan ketentuan apabila denda tersebut tidak dibayar maka diganti dengan pidana kurungan selama 1 (satu) bulan. Kemudian lewat kuasa hukumnya pada Lembaga Bantuan Hukum "SHS "yang berkantor di Jalan Patriot Nomor 40 Purwokerto berdasarkan surat kuasa tanggal 30 Maret 2009, mengajukan banding atas putusan Pengadilan Negeri Kabupaten Purbalingga. Yang kemudian Pengadilan Tinggi Jawa Tengah menguatkan putusan Pengadilan Negeri Kabupaten Purbalingga. Pada tahapan kampanye aturan dari KPU berubah-ubah sampai 3 kali, ini jelas menjadikan strategi kampanye masing-masing kontestan dan caleg merubah tips dan trik nya. .Ini bisa ada korelasinya antara putusan Mahkamah Konstitusi dengan menggantinya dengan per- olehan suara terbanyak, sehingga para caleg mengubah strateginya menggunakan cara lain.

Kebanyakan kampanye terbuka di Kabupaten Purbalingga tidak digunakan oleh Peserta Kampenye, karena dari pengamatan dan pengawasan Panwaslu bahwa kampanye terbuka sengaja tidak digunakan dengan maksud akan menggunakan kampanye terselubung pada masa tenang dengan money politk. Sehingga Panwaslu mengadakan pola bahwa pada hari tenang diinstruksikan Panwaslu Kecamatan dan PPL wajib 24 jam untuk siaga satu, karena terjadinya perubahan pola kampanye dari masing-masing caleg tersebut.

Keenam, masa tenang. Pada saat masa tenang antara tanggal 6, 7, 8 April 2009, banyak sekali ditemukan pelanggaran pidana, tetapi karena terbatasnya pengetahuan para Pengawas khususnya di tingkat Pengawas Lapangan dan Panwascam, maka banyak sekali pelanggaran pidana yang lolos dari pengawas kawan-kawan di tingkat PPL dan Panwascam. Keterbatasan waktu dalam memberikan bekal pengawasan kepada panwaslu kecamatan dan PPL merupakan awal permasalahan yang terjadi di Kabupaten Purbalingga. Sehingga dalam pengawasannya sangat tidak maksimal. Ditambah lagi tidak sebandingnya jumlah PPL dengan luasnya wilayah kepengawasan. Namun demikian, Panwaslu seluruh kabupaten tidak mau tinggal diam, karena sudah menjadi komitmen untuk menjadi Pengawas Pemilu agar Pemilu berjalan langsung, jujur dan adil serta beradab, maka Panwaslu Se-Kabupaten Purbalingga tetap dengan semangat mengadakan pengawasan pada saat tahapan hari tenang. Pada masa tenang ini Panwaslu Kabupaten Purbalingga menerima laporan dugaan money politik sebanyak 10 laporan dugaan money politik pada masa tenang, yang mana 7 kasus di cabut oleh pelapor, 2 kasus dihentikan karena tidak memenuhi unsur.

Ketujuh, pemungutan dan penghitungan suara. Proses pemungutan dan penghitungan suara adalah momentum dari semua tahapan Pemilu. Dalam proses pemungutan dan penghitungan suara Panwaslu se-kabupaten Purbalingga mengadakan pengawasan secara serem- 
pak, yang dibantu oleh beberapa pemantau pemilu. Ini menandakan bahwa walaupun kesiapan perangkat lunak (software) yaitu pelatihan dan pembekalan yang diberikan kepada PPL nyaris sangat-sangat minim, tetapi dengan semangat ke-Indonesiaan PPL dan Panwaslu kecamatan tetap mengadakan pengawasan dengan bekal minim pula. Memang sangat mengecewakan ketika dalam pungut-hitung suara dengan cara pola pemilu tahun 2009 yang berubah-ubah ini akan tetapi tidak ditemukan satu pelanggaran pidana satu pun di Kabupetan Purbalingga yang diteruskan kepada penyidik. Dalam proses Pemungutan dan penghitungan suara tersebut, panwaslu tidak menerima laporan dan tidak menemukan tindak pidana pemilu tahap Pemungutan dan Penghitungan Suara.

Kedelapan, penetapan hasil pemilu. Proses penetapan hasil pemilu telah dilakukan oleh KPU Kabupaten Purbalingga dan penetapan perolehan kursi dan penetapan calon anggota DPRD Kabupaten Purbalingga terpilih pada tanggal 17 Mei 2009. Sejauh pengawasan Panwaslu kabupaten Purbalingga tidak menemukan atau menerima laporan pelanggaran tindak pidana pemilu. Walaupun KPU Kabupaten Purbalingga melakukan revisi penetapan karena harus menjalankan putusan Mahkamah Konstitusi.

Kesembilan, pengucapan sumpah/janji anggota DPR, DPD, dan DPRD. Tahap akhir dari kegiatan pemilu adalah tahap pengucapan sumpah dan janji calon anggota DPR terpilih. Dalam hal ini calon anggota DPRD Kabupaten Purbalingga ditetapkan 45 calon anggota DPRD Kabupaten Purbalingga terpilih. Karena proses ini belum terlaksana, maka tahapan ini Panwaslu kabupaten Purbalingga belum bisa mengadakan pengawasan, namun sejauh pemantauan Panwaslu tidakada masalah yang berarti dalam pelaksanaan pengambilan sumpah dan janji anggota DPRD Kabupaten Purbalingga yang terpilih yang sedianya akan dilaksanakan pada tanggal 19 Agustus 2009.

Berdasarkan hasil penelitian di Kabupaten Banyumas dan Purbalingga ternyata peran penegakan hukum dan peran masyarakat dalam Pemilu Legislatif 2009 amat berpengaruh ter- hadap jalannya Pemilu 2009. Hal tersebut di pengaruhi oleh peran masyarakat (baca Partai Politik peserta Pemilu) untuk mempengaruhi penegakan hukum dalam penindakan baik unsur pidana maupun unsur administratif tindak pidana Pemilu. Itu bisa dilihat dari kasus pidana Pemilu di Kabupaten Banyumas dan Purbalingga.

Menurut pendapat yang dikemukakan oleh Friedman, bahwa sistem hukum meliputi substansi, struktur, dan budaya hukum, berikut uraian masing-masing elemen, ${ }^{3}$ yaitu pertama, Substansi hukum adalah aturan, norma dan pola tingkah laku manusia yang berada dalam sistem itu. Pengertian substansi tidak hanya terbatas pada hukum tertulis, tetapi juga hukum yang hidup dan berlaku dalam masyarakat; kedua, struktur hukum adalah yang merupakan institusional kedalam lintas hukum seperti pengadilan tingkat pertama, banding dan kasasi, serta integrated criminal justice system; ketiga, budaya hukum adalah sikap-sikap dan nilai-nilai yang berhubungan dengan hukum, yang terkait dengan tingkah laku yang berhubungan hukum dengan lembaganya, baik positif maupun negatif.

Menurut I.S.Susanto, dalam mempelajari bekerjanya hukum berarti mempelajari kondisikondisi sosial, ekonomi, politik, budaya (termasuk hukumnya) yang "mempengaruhi" dalam arti luas yakni mempelajari aspek struktur, kultur dan substansinya. Dalam bekerjanya hukum, maka diperlukan adanya suatu pengawasan, karena pengawasan merupakan suatu hal yang sangat penting agar seluruh pelaksanaan tugas dilaksanakan sesuai ketentuan. ${ }^{4}$

Faktor penentu kesadaran hukum masyarakat sangat dipengaruhi oleh bekerjanya berbagai faktor dan kekuatan yang ada. Dalam hal ini bahwa tindakan yang akan dilakukan oleh warga masyarakat sebagai respon terhadap peraturan-peraturan hukum sangat tergantung dari isi norma hukum itu sendiri, sanksisanksinya, aktivitas para pelaksana hukum serta semua faktor-faktor yuridis yang bekerja atas dirinya. Dengan demikian, harus dapat

\footnotetext{
3 Ibid. hlm. 11-13.

4 Ibid. hlm.19.
} 
dipahami bahwa setiap undang-undang yang dikeluarkan atau dibuat akan mengalami perubahan, baik melalui perubahan formal maupun melalui cara-cara yang ditempuh birokrasi ketika bertindak. Perubahan itu terjadi disebabkan oleh adanya kekuatan-kekuatan sosial, ekonomi dan sebagainya yang bekerja memberikan impaknya. ${ }^{5}$

Alur bekerjanya hukum dalam berbagai lingkup dan berbagai faktor kekuatan tersebut, dapat dicermati melalui bagan Chambliss dan Robert B. Seidman yang dikutip oleh Esmi Warassih sebagai berikut: ${ }^{6}$

Bagan 4.

Bekerjanya Hukum

Bekerjanya kekuatan-kekuatan personal \& sosial

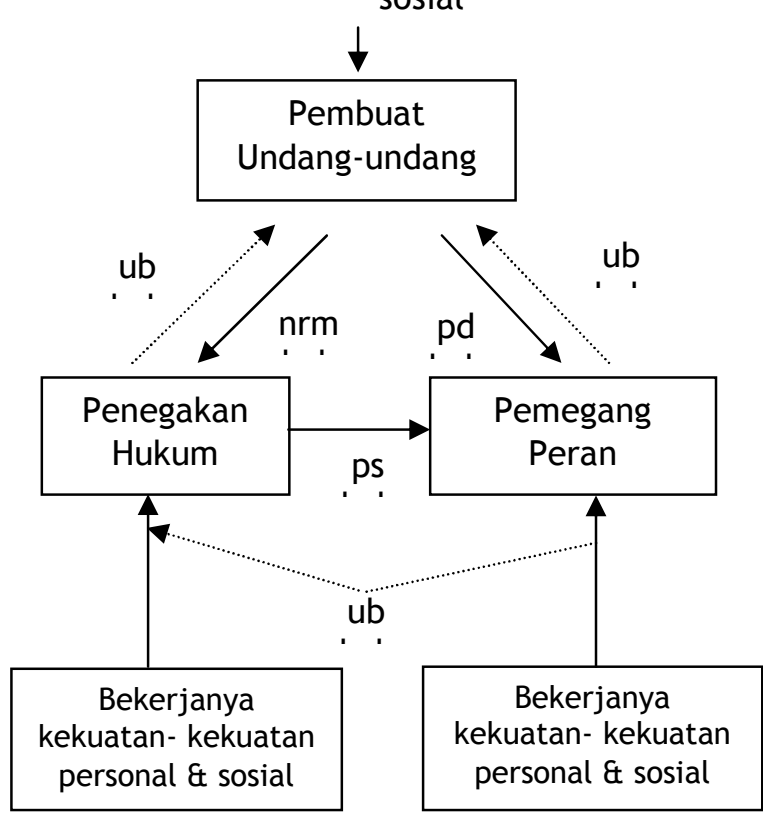

Keterangan:

$\mathrm{ub}=$ umpan balik

$\mathrm{nrm}=$ norma

pd = peran yang dimainkan

ps = penerapan sanksi

Dari bagan tersebut di atas dijelasakan bahwa proses bekerjanya hukum itu sangat ditentukan oleh beberapa faktor penting, yaitu ${ }^{7}$ pertama, peraturan-peraturan hukumnya; ke- dua, badan pembuat undang-undang; ketiga, badan pelaksana hukum (sanctioning agencies); keempat, masyarakat sebagai sasaran pengaturan (dalam diagram dukualifikasikan sebagai pemegang peran, yang berarti peranannya di dalam masyarakat ditentukan oleh apa yang dirumuskan di dalam peraturan); kelima, proses penerapan hukum; keenam, komunikasi hukumnya; ketujuh, kompleks kekuatan sosial politik dan lain-lain yang bekerja atas diri pembuat undang-undang, birokrasi (pelaksana hukum) maupun masyarakat sendiri sebagai pemegang peran; dan kedelapan, proses umpan balik antara semua komponen tersebut.

Model dari Chambliss dan Seidman tersebut di atas, telah menjelaskan pengaruh faktor-faktor atau kekuatan-kekuatan sosial mulai dari tahap pembuatan undang-undang, penerapannya, dan sampai kepada peran yang di harapkan. Dari uraian di atas menunjukan bahwa hukum merupakan suatu proses sosial yang dengan sendirinya merupakan variabel yang mandiri (otonom) maupun tidak mandiri (tidak otonom) sekaligus. ${ }^{8}$

Disadari atau tidak bahwa kekuatan-kekuatan sosial sudah mulai bekerja dalam tahapan pembuat undang-undang. Kekuatan-kekuatan sosial itu akan terus berusaha untuk masuk dan mempengaruhi setiap proses legislasi secara efektif dan efisien. Adapun peraturan yang dikeluarkan itu memang bakal menimbulkan hasil yang diinginkan, tetapi efeknya itu pun sangat tergantung pada kekuatan-kekuatan sosial yang melingkupinya. ${ }^{9}$

Demikian pula, pengaruh kekuatan-kekuatan sosial dirasakan juga dalam bidang penerapan hukum. Gustav Radbruch, mengemukakan adanya tiga nilai dasar yang ingin dikejar dan perlu mendapat perhatian serius dari para pelaksana hukum, yakni nilai keadilan, kepastian hukum dan kemanfaatan. Terutama nilai dasar kemanfaatan ini akan mengarahkan hukum pada pertimbangan kebutuhan masyarakat pada suatu saat tertentu, sehingga hukum

\footnotetext{
5 Esmi Warassih, 2005, Pranata Hukum Sebuah Telaah Sosiologis, Semarang: Penerbit PT. Suryandaru Utama. $\mathrm{h} l \mathrm{~m} .121$.

6 Ibid. hlm.12.

7 Ibid. hlm.121-122
}

8 Ibid. hlm. 13.
9 Ibid. 
itu benar-benar mempunyai peranan yang nyata bagi masyarakat. ${ }^{10}$

Sehubungan dengan masalah penegakan hukum ini, Soerjono Soekanto mengemukakan bahwa masalah pokok dari pada penegakan hukum sebenarnya terletak pada faktor-faktor yang mempengaruhinya. Faktor-faktor tersebut mempunyai arti yang netral, sehingga dampak positif dan negatifnya terletak pada isi faktorfaktor tersebut. Faktor-faktor tersebut adalah sebagai berikut: Faktor hukumnya sendiri, dalam tulisan ini dibatasi pada undang-undangnya saja; Faktor penegak hukum, yakni pihak-pihak yang membentuk maupun yang menerapkan hukum; Faktor sarana atau fasilitas yang mendukung penegakan hukum; Faktor masyarakat, yakni lingkungan dimana hukum tersebut berlaku atau diterapkan; Faktor kebudayaan, yakni sebagai hasil karya, cipta dan rasa yang didasarkan pada karsa manusia dalam pergaulan hidup. Kelima faktor ini saling berkaitan erat, karena hal tersebut merupakan esensi dari penegakan hukum, serta juga merupakan tolok ukur daripada efektivitas hukum itu sendiri. ${ }^{11}$

Sebagai pisau analisis menurut Chambliss dan Robert B. Seidman dalam penerapan tindak pidana Pemilu menurut Undang-Undang Nomor 10 Tahun 2008 Tentang Pemilu yang terjadi penulis menyampaikan bahwa, pertama, pembuat Undang-Undang (Pemerintah) tidak konsisten untuk melaksanakan aturan-aturannya sendiri, yaitu dengan tidak segera membentuk perangkat Undang-Undang secara bersamaan antara KPU dan Panwaslu, ada jeda dalam penetapan antar lembaga, ini akan berakibat pelaksanaan dilapangan yang tidak pasti, aturan yang berubah-ubah membuat proses hukum tidak pasti.

Kedua, dalam penegakan hukumnya, penegak hukum melaksanakan tugas dengan setengah-setengah, antara penyidik, penuntut dan pemutus perkara tidak sepenuhnya berdasarkan pada undang-undang akan tetapi masih melihat juga KUHP. Pendeknya batasan

\footnotetext{
${ }^{10}$ Satjipto Raharjo, 2006, Ilmu Hukum. Bandung: Penerbit PT. Citra Aditya Bakti, hlm. 19.

11 Soerjono Soekanto, 1993, Faktor-Faktor Yang Mempengaruhi Penegakan Hukum, Jakarta: P.T. Raja Grafindo Persada, hlm.6.
}

pemutusan perkara pidana pemilu yang mengakibatkan perkara bisa dipatahkan tanpa proses peradilan (misalnya tidak cukup bukti, daluarsa dan pemberhentian pemeriksaan oleh penyidik).

Ketiga, masih dominannya pengaruh partai-partai besar yang mempengaruhi proses hukum, mengakibatkan kecenderungan hakim agak gamang memutus perkara, lain kalau perkara melibatkan partai baru atau partai kecil hakim akin menjatuhkan putusan dengan tegas.

Keempat, masyarakat juga belum terdidik secara sumber daya politik, ini bisa dilihat dengan memilih peserta pemilu hanya demi uang (money politic) yang sangat sulit dibuktikan; karena terbentur aturan-aturan yang tidak tegas dan jelas. Sementara peserta pemilu legislatif, tidak memahami apa arti demokrasi yang sesungguhnya, yaitu suara rakyat yang tertinggi. Masyarakat tidak/belum paham hakekat pelanggaran dan tindak pidana Pemilu.

\section{Penutup \\ Simpulan}

Berdasarkan uraian pembahasan tersebut di atas, maka dapat disimpukan beberapa hal sebagai berikut. Pertama, identifikasi terhadap perumusan tindak pidana pemilu dalam Undang-undang Nomor 10 Tahun 2008 Tentang Pemilu dapat disimpulkan bahwa dari aspek perbuatan, pelaku dan sanksi pidana terdapat kekhususan dibandingkan dengan tindak pidana umum.

Kedua, penerapan Tindak Pidana Pemilu Tahun 2009 di Kabupaten Banyumas dan Kabupaten Purbalingga sebanyak 94 tindak pidana pemilu dengan rincian 51 terjadi di Kabupaten Banyumas dan 43 terjadi di Kabupaten Purbalingga. Dari 94 tindak pidana pemilu tersebut hanya 3 tindak pidana pemilu yang diproses hukum, karena cukup bukti dan memenuhi aturan undang-undang, yaitu 2 di Kabupaten Banyumas dan 1 di Kabupaten Purbalingga, 2 putusan berkekuatan hukum tetap dan telah mengajukan upaya hukum sesuai dengan undang-undang dan juga telah ditetapkan oleh Pengadilan Tinggi, sementara putusan yang sa- 
tunya melepaskan terdakwa dari segala tuntutan hukum atau ontslag van ale rechtvervolging (di Kabupaten Banyumas), juga telah mengupayakan hukum dan mendapat putusan dari Pengadilan Tinggi. Sementara 91 tindak pidana pemilu tidak dapat dilanjutkan karena, tidak cukup bukti, dan daluarsa.

\section{Saran}

Saran yang dapat diberikan sehubungan dengan pemecahan atas permasalahan tersebut di atas adalah sebagai berikut. Pertama, perlunya penegasan sanksi pidana dalam undangundang ini khususnya bagi penegakan hukum yang menyangkut tindak pidana pemilu, karena sanksi pidana dan denda tidak dipisahkan (kumulatif). Banyaknya Partai peserta pemilu yang banyak melakukan pelanggaran Pemilu dalam undang-undang ini. Undang-undang ini perlu direvisi, dalam hal sanksi dan denda, minimal dan maksimumnya. Waktu yang amat pendek dalam proses hukum (14 hari) perlu ditinjau kembali.

Kedua, dalam penerapan undang-undang ini fungsi penegakan hukum harus tegas dilakukan, oleh aparat yang ditunjuk oleh undangundang, baik polisi, kejaksaan dan pengadilan. Karena terbukti dari tindak pidana pemilu yang terjadi di Kabupaten Banyumas (51 tindak pidana) dan Purbalingga (43 tindak pidana) yang diproses sampai ditingkat putusan hanya 3 dari 93 tindak pidana yang terjadi di 2 kabupaten. Penghentian penyidikan di tingkat kepolisian dan kejaksaan jangan mudah dilakukan, harus diselesaikan dengan sungguh-sungguh. 